\title{
Research article: Comparative economics of production and marketing of MAUS-71 and JS-335 of soybean varieties of Parbhani district
}

\section{G.H. KAUSADIKAR, S.H. KAMBLE AND BANDI SRIKANTH}

Article Chronicle:

Received :

15.07.2017;

Accepted :

30.07.2017

KEY WoRDS:

Socio economic characteristics, Profitability, Resource use efficiency
SUMMARY : The study compared the economic performance of MAUS-71 and JS-335 soybean in Parbhani district, State of Maharashtra, with the aim of assessing the determinants of its profitability. Primary data obtained from a sample of 120 farmers by stratified and multi-staged random sampling from four villages were analyzed using percentages, means, gross margin, net profit, marginal product, optimum resource use efficiency, return to scale and F- value. Results revealed gender inequality; Majority of MAUS-71 respondents were in above 45 years age group and in case of JS-335 respondents were middle age group. Net profit obtained by cultivation MAUS-71 Rs. 24671.09 than that of JS-335 was 19958.7; The $\mathrm{R}^{2}$ value indicated that 79 per cent and 82 per cent variations in MAUS-71 and JS-335 varieties of soybean, respectively. Results also showed that area, phosphorus, family labour, were highly significant at one per cent levels and positively correlated with farmers' profit in MAUS-71 soybean; while in case of JS-335, area, seed, plant protection and family labour were positively significant at one per cent level. The study concludes that cultivation of MAUS-71 variety of soybean was found to be profitable over JS-335 variety.

How to cite this article : Kausadikar, H.H., Kamble, S.H. and Srikanth, Bandi (2017). Comparative economics of production and marketing of MAUS-71 and JS-335 of soybean varieties of Parbhani district. Agric. Update, 12(TECHSEAR-5) : 1318-1322; DOI: 10.15740/HAS/AU/12.TECHSEAR(5)2017/1318-1322.
Author for correspondence :

\section{H.H. KAUSADIKAR}

Department of Agricultural Economics, College of Agriculture, LATUR (M.S.) INDIA Email :

harshakausadikar@ gmail.com

See end of the article for authors' affiliations 